\title{
The Strategy of Phytoplankton on Critical Conditions in Coastal Waters
}

\author{
Rahmadi Tambaru*, Muh. Farid Samawi, Khairul Amri \\ Department of Marine Science, Faculty of Marine Science and Fisheries, Universitas Hasanuddin, \\ Indonesia. \\ * Corresponding author's e-mail: aditbr69@yahoo.com
}

How to Cite: Tambaru, R., Samawi, M.F., and Amri, K. (2020). The Strategy of Phytoplankton in Critical Conditions In Coastal Waters . Int. J. Agr. Syst. 8(1): 11-16

\begin{abstract}
The productivity of phytoplankton found best in coastal waters is on a critical aquatic environmental condition for the life of phytoplankton (incubation time: 10.00-14.00). At that incubation time, the sun reached the apex of illumination (12.00). Theoretically, the best productivity is unlikely to happen because the activity of phytoplankton is not perfect. To answer that doubt, the research deals with the strategy of life phytoplankton on critical conditions in coastal waters. To achieve the desired results, multivariate analysis is used Correspondent analysis (CA) and Principal Components Analysis $(P C A)$. The results showed that based on the analysis of Factorial Koresponde (CA), there were two grouping of phytoplankton abundance. Group I showed that the grouping of phytoplankton abundance of occurred at $A$ depth of $10 \mathrm{~m}$ at the sampling time A (10.00 : normal conditions). Group II occurs at a depth of 5 and $15 \mathrm{~m}$ at sampling time B (14.00: critical condition). Furthermore, the shift in grouping phytoplankton occurs at the sampling time $A$ at a depth of $10 \mathrm{~m}$ into the sampling time $B$ in $5 \mathrm{~m}$ depth, not at at a depth of $0 \mathrm{~m}$. This is due to the very strong sunlight intensity that can lead to death in the genera of phytoplankton that exist. It turns out that the strategy and the dynamics of phytoplankton abundance at critical time is not doing the grouping at the surface depth $(0 \mathrm{~m})$, but at a deeper depth $(5 \mathrm{~m})$ in order to keep the activity well done.
\end{abstract}

Copyright $\odot 2020$ IJAS. All rights reserved.

\section{Keywords:}

Strategy; Abundance; Phytoplankton; Critical Conditions; Coastal Waters

\section{Introduction}

Coastal waters have high biological resources (Karydis, 2009). It is supported by physical, chemical and biological conditions (Duarte et al., 2000). The waters are the most widely known and studied parts of the sea waters. The region is easy to reach by humans (Wang et al., 2016). Although the area is limited, there are a variety of environmental parameters (Iosjpe, 2011) when compared to other marine regions. In this area there are also many interesting phenomena to be researched (Cosgrove, et al., 2015).

In coastal areas, phytoplankton can perform the process of photosynthesis effectively (Mosharova et al., 2018). In conducting activities, these microorganisms are highly 
dependent on the availability of nutrients and light (Cloern et al., 2014). Both parameters have a strong influence, synergize in supporting the growth of phytoplankton ( $\mathrm{Li}$ et al., 2014). If the availability of both is sufficient, then phytoplankton activities can run well. In case of fluctuations in nutrient availability and light, the growth of phytoplankton will reveal its own dynamics.

Particularly light, its presence in coastal waters became the most mainstream abiotic factor, not a nutrient that strongly determines the primary productivity rate of phytoplankton (Bhutiani et al., 2009). In the process, the solar light energy is overhauled into the subsequent chemical energy (Karl, 2014) used by phytoplankton to synthesize complex organic compounds through the process of photosynthesis (Puskaric and Mortain-Bertrand. 2003). The formed organic material then transferred through the process of predation by the organism at each trophic level until the highest.

Therefore, if the penetration of the sunlight is obstructed and only reaches a low depth in the water layer, then the thickness of the water layer that gets light is thin. This causes the primary production to be low because the photosynthesis process of phytoplankton is not perfectly lasting (Hader et al., 2007). Phytoplankton as capture of a solar light (Charalampous et al., 2018), of course, it must live on the water layer with sufficient light (the euphotic zone) (Ryabov et al., 2010). However, not all types of phytoplankton have the same adaptation ability to light. There is a difference in the content of pigment and its physiological structure, it causes the type to have a different response to light. Thus, at any depth of the water will be obtained differences in the types of phytoplankton.

The amount of light intensity in coastal waters can change with increasing depth. Angles come sunlight and the position of the water (latitude and longitude) is another factor that can cause the change of light intensity in the layers of the water. The angle of sunlight depends on the travel of the sun for a day, different from the day and evening as well as the difference in each hour. This incident certainly affects the magnitude of primary production through the photosynthesis of phytoplankton. The primary production of phytoplankton will be found to vary from one location to another in one water, as well as from one water to another (Kaswadji et al., 1993).

In many research results by experts get the conclusion that the process of photosynthesis goes perfectly on the coming sun angles are on the apex of illumination about 12.00. More specifically, the research carried out by Tambaru and Samawi in 2002 in the waters of Barrang Lompo Island resulted in one conclusion that the primary productivity of the highest phytoplankton was found in critical environmental conditions for the life of phytoplankton (incubation time 10.00-14.00). Theoretically, the above is unlikely. There is a very high illumination of the sun at the incubation time, thus making phytoplankton activities do not go perfectly. But why does it get the highest primary productivity measurement results? The question was missed through research on the strategy and life dynamics of phytoplankton abundance at the best incubation time (10:00-14:00) in the coastal waters of Barrang Lompo island of Makassar. The research deals with the strategy of life phytoplankton on critical conditions in coastal waters.

\section{Method}

The research was carried out in the waters of Barrang Lompo Island of Makassar. Research is conducted at four depths of $0 \mathrm{~m}, 5 \mathrm{~m}, 10 \mathrm{~m}$, and $15 \mathrm{~m}$. Interval of the 
Incubation time used is 10:00-14:00. At that time, research was conducted in 10.00 and 14.00. To see the phytoplankton abundance, the water sampling for identification is implemented at the time of sampling A (10:00 = stable condition) and B (14:00 = critical condition). The water samples were subsequently analyzed at the Oceanographic Chemistry Laboratory at the Faculty of Marine Sciences and Fisheries, Hasanuddin University. For nutrient measurements (orthophosphate, nitrate, and silicate), water samples were taken together with water sampling for phytoplankton specimens. At that time, a measurement of physics-chemical parameters (temperature, salinity, and $\mathrm{pH}$ ) was measured.

To describe the distribution of the spasio-temporal of phytoplankton abundance, then used multivariate analysis of the Correspondent analysis (CA) followed the instructions of Legendre and Legendre (1993) and Bengen (2000). This analysis can give an overview of grouping phytoplankton in critical conditions on the water column. For testing linkage between physical-chemical variables with sampling time and depth by using Principal Components Analysis (PCA) (Bengen, 2000).

\section{Results and Discussion}

\subsection{Environmental parameters and Composition of phytoplankton}

The results of environmental parameter measurements (nitrates, orthophosphate, silicate, temperature, degree of acidity $(\mathrm{pH})$, and salinity) are still in the range corresponding to the growth of phytoplankton. Furthermore, the composition of phytoplankton found consists of 3 classes and 20 genera which are the Bacillariophyceae of 11 genera, the Chlorophyceae as much as 4 genera, and the Cyanophyceae as much as 5 genera. Diatoms and the Bacillariophyceae are the most dominant genera and classes of phytoplankton at the time of sampling A and B.

\subsection{The strategy and dynamics of abundance phytoplankton}

\subsubsection{Distribution of spasio-temporal of phytoplankton abundance}

Distribution of the spasio-temporal of phytoplankton abundance at the time of sampling A and B in 4 depth of water was analyzed by a correspondent factorial analysis (CA). From a graphical representation (Fig. 1), between the main factorial axes 1 and 2 (F1 and F2) shows grouping of phytoplankton abundance. Figure 1 depicts that there are two groups of phytoplankton abundance. Group I demonstrated phytoplankton abundance at the time of sampling A (A1, A2, and A3) in groups and had a close relationship with a depth of $10 \mathrm{~m}$. Group II demonstrated phytoplankton abundance at sampling time B (B1 and B2) tend to group and have close relationship with depth 5 and $15 \mathrm{~m}$. Of the two groups above, grouping phytoplankton abundance occurs during research. Grouping phytoplankton abundance is very differently reviewed from the sampling time and depth of water.

The occurrence of grouping phytoplankton indicates the suitability and the relation of relationships occurring at the time of sampling and depth in which the group is formed. The suitability and relevance of this relationship can occur due to certain environmental parameters that affect the depth in which the grouping occurs. 


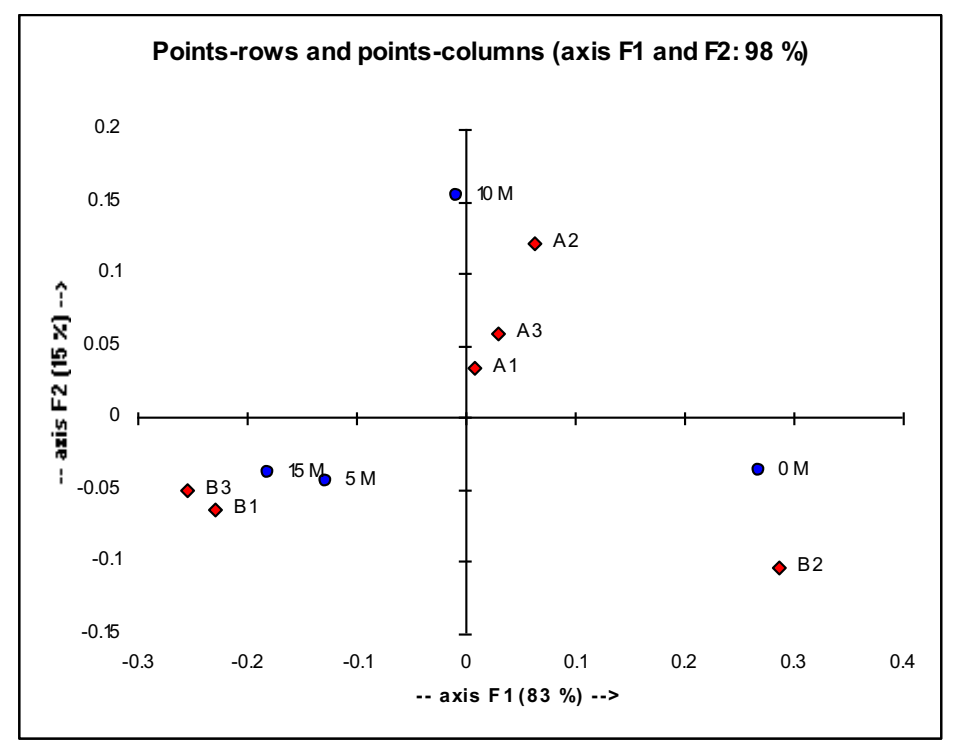

Figure 1. Graphical representation of factorial axes 1 and 2 (F1 and F2) group phytoplankton abundance based on sampling time and water depth

\subsubsection{Environmental parameters relationship}

To emphasize that environmental parameters have an influence on grouping the abundance of phytoplankton, it is performed analysis of physical-chemical parameters at various sampling time and depth. The analysis used is Principal Component Analysis (PCA). It can explain about any parameter that characterizes/affects the various sampling times and the depth of water. From the overlay result between the variable distribution plot and the observation on F1 and F2 (Fig 2) clearly shows that each sampling time and depth is characterized by the presence of one or more different the identifier variables. The most dominant characteristic variable at the time of sampling A is nitrate and silicate, while that at the time of sampling B is salinity.

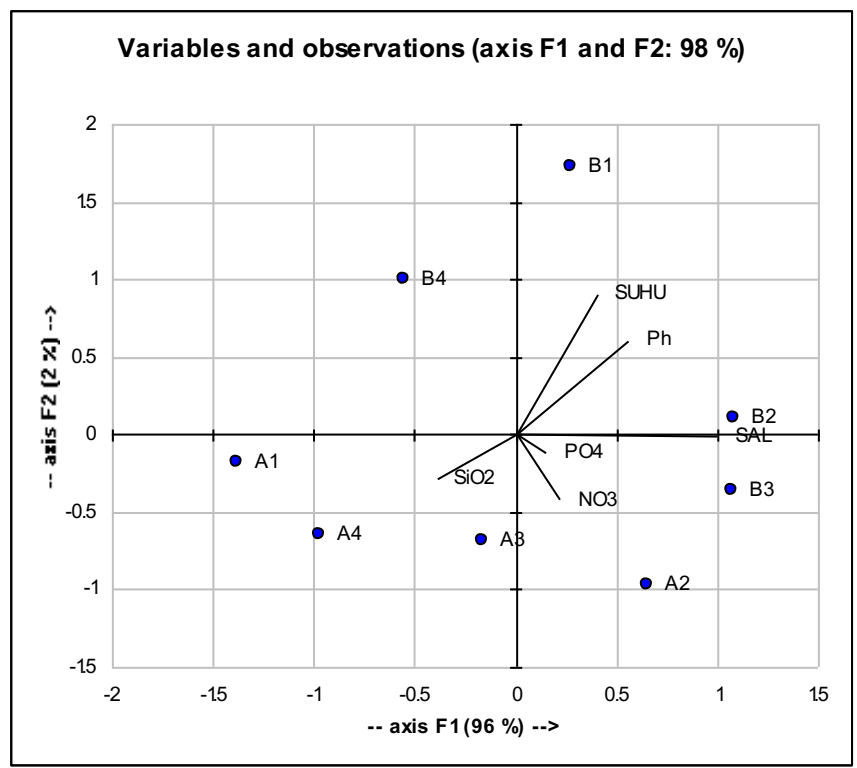

Figure 2. Combined plot between station observation and variables on axes 1 and 2 (F1 and F2) 
The presence of a variable characterizes at various times of sampling and the depth above emphasises that the grouping of abundance of phytoplankton (results of FCA analysis) is occurring at every sampling time and depth of water. The detailed explanation concerning both the CA and PCA analysis results in relation to the strategy and the abundance dynamics of phytoplankton can be explained as follows: Review of the sampling time and depth can be explained that grouping phytoplankton (Fig. 1) at the time of sampling A at A depth of $10 \mathrm{~m}$ shifted to the sampling time B at a depth of $5 \mathrm{~m}$. This happens because of the difference in the value of salinity.

Generally speaking at A sampling time A, the value of the salinity range is found lower compared to the value of the range $B$. This causes the types of phytoplankton at the time of sampling $B$ to be more active and in accordance with its development. Some types of phytoplankton that were previously not able to activity well because of low salinity value became optimal when the value of salinity became higher. Consequently, abundance at the sampling time $B$ is found higher.

The occurrence of the shifting group of abundance phytoplankton also caused the conformity with sun intensity. At the time of sampling A, sunlight has not been absorbed much by phytoplankton because its exposure is still slightly entering the water. The occurrence of grouping phytoplankton at A depth of $10 \mathrm{~m}$ at the time of sampling $\mathrm{A}$ is not due to growth, but due to the treatment of phytoplankton at night. In times of low light intensity, most phytoplankton sink to near the base of the water. Therefore, at the time of sampling A was carried out, obtained grouping phytoplankton is precisely found in the water column near the base of waters $(10 \mathrm{~m})$. This condition is contrary to grouping phytoplankton at the time of sampling B. At the time of sampling B clearly the group shifts the abundance to a column near the surface. The occurrence of this shift caused greater light intensity into the water. This causes the phytoplankton to grow in depth with greater beam intensity (Duarte, et al., 2000). Surely the depth in question is the close depth of the surface $(5 \mathrm{~m})$, but not the depth of $0 \mathrm{~m}$. No grouping at $0 \mathrm{~m}$ depth caused by the intensity of sunlight is precisely very strong. This can lead to death in the type of phytoplankton. It turns out that the strategy and the abundance dynamics of phytoplankton at critical time is not doing the grouping at the surface depth $(0 \mathrm{~m})$, but at a deeper depth $(5 \mathrm{~m})$ in order to keep the activity well done.

\section{Conclusion}

It can be concluded that the strategy and the abundance dynamics of phytoplankton at critical time (time 10.00-14.00) is grouping at a deeper depth i.e. at $5 \mathrm{~m}$, not the surface depth $(0 \mathrm{~m})$, in order to keep phytoplankton activity is doing well.

\section{References}

Bengen D G. 2000. Teknik pengambilan contoh dan analisis data biofisik sumberdaya pesisir. Sinopsis. Pusat Kajian Sumberdaya Pesisir dan Lautan, Fakultas Perikanan dan Ilmu Kelautan, Institut Pertanian Bogor.

Bhutiani R, Khanna D R., Chandra K S. 2009. Light-limited population dynamics of phytoplankton: modeling light and depth effects. Environmentalist. 29:93-105.

Charalampous E., Matthiessen B, and Sommer U. 2018. Light effects on phytoplankton morphometric traits influence nutrient utilization ability. Journal of Plankton Research. 40 (5) : 568-579. 
Cloern J E., Foster S Q., and Kleckner A E. 2014. Phytoplankton primary production in the world's estuarine-coastalecosystems. Biogeosciences. 11: 2477-2501.

Cosgrove W J. and Loucks, D P. 2015. Water management: current and future challenges and research directions. Water Resources Research. 51: 4823-4839.

Duarte C M., Agustí S., Gasol J M., Vaqué D., Dominguez E V. 2000. Effect of nutrient supply on the biomass structure of planktonic communities: an experimental test on a Mediterranean coastal community. Mar. Ecol. Prog. Ser. 206: 87-95.

Hader D P., Kumar H D., Smith R C, and Worrest R C. 2007. Effects of solar UV radiation on aquatic ecosystems and interactions with climate change. Photochemical \& Photobiological Sciences. 6: 267-285.

Iosjpe M. 2011.Evaluation of the environmental parameters controlling the vulnerability of the coastal marine regions. Radioprotection. 46: 289-293.

Karl D M. 2014. Solar energy capture and transformation in the sea. Elementa Science of The Anthropocene, 2, p.000021.

Karydis M. 2009. Eutrophication assessment of coastal waters based on indicators: a literature review. Global NEST Journal. 11 (4) : 373-390.

Kaswadji R. F. 1999. Pengaruh angin terhadap penyebaran biomassa fitoplankton di Teluk Pelabuhan Ratu. Jurnal Ilmu-ilmu Perairan dan Perikanan Indonesia. VI(2): 61-72.

Legendre L., dan P. Legendre. 1993. Numerical ecology. Second English Edition. Elsevier Science B.V., Amsterdam.

Li R H., Liu S M., Li Y W., Zhang G L., Ren J L., and Zhang J. 2014. Nutrient dynamics in tropical rivers, lagoons, and coastalecosystems of eastern Hainan Island, South China Sea. Biogeosciences. 11:481-506.

Mosharova S A., Sergeeva V M., Kremenetskiy V V, Sazhin A F., Stepanov S V. 2018. Assessment of phytoplankton photosynthetic efficiency based onmeasurement offluorescence parameters and radiocarbon uptake in the Kara Sea. Estuarine, Coastal and Shelf Science. 218 : 59-69.

Puskaric S., and Mortain-Bertrand A. 2003. Physiology of diatom skeletonema costatum (Grev.) cleve photosynthetic extracellularrelease : evidence for a novel coupling between marine bacteria and phytoplankton. Journal of plankton research. 25(10):1227-1235.

Ryabov A B, Rudolf L., and Blasius B. 2010. Vertical distribution and composition of phytoplankton under the influence of anupper mixed layer. Journal of Theoretical Biology. $263: 120-133$.

Tambaru R. dan Samawi M F. 2002. Penentuan selang waktu inkubasi yang terbaik dalam pengukuran produktifitas primer di perairan Kepulauan Spermonde. Laporan Penelitian BBI, DIKTI-LP UNHAS, Makassar. p33.

Wang L., Li Q., Bi H., and Mao X Z. 2016. Human impacts and changes in the coastal waters of south China. Science of the Total Environment. 562: 108-114. 